\title{
UPAYA MENINGKATKAN KINERJA GURU MELALUI SUPERVISI AKADEMIK DI SD NEGERI 001 GUNUNG KIJANG KEPULAUAN RIAU
}

\author{
Suyatno \\ SD Negeri 001 Gunung Kijang \\ Email: suyatnosdn001gunungkijang@gmail.com
}

\begin{abstract}
Performance of teacher is reached result of them in executing based duties of efficiency, seriousness and experience and also usage of time in course of learning to teach in school. Teacher performance will good if teacher have executed elements which consist of and faithfulness of commitment the highness at duty teach, mastering and developing lesson materials, discipline in teaching and other duty, creativity in executing instruction, cooperation with all school citizens, leadership becoming student peer, good personality, ad for and objective in guiding student, and also responsibility to his duty. Research focused 1. Strategy any kind of done by headmaster in improving teacher professionalism in SD Negeri 001 Gunung Kijang Kabupaten Bintan? 2. Factor any kind of becoming supporter and constraint in improvement teacher professionalism in SMP N 4 Gunung Kijang Kabupaten Bintan? 3. How effort the done by headmaster in handling constraint factor oflis make-up of teacher professionalism in SD Negeri 001 Gunung Kijang Kabupaten Bintan? Method Research weared in this research is device qualitative with method intake of data through interview, documentation and observation to informan namely components in SD Negeri 001 Gunung Kijang Kabupaten Bintan. While data analysis through analysis of interaktif.
\end{abstract}

\section{Keyword: Effort To Improve, Teacher Performance, Academic Supervision}

\section{PENDAHULUAN}

Guru adalah sumber daya manusia di sekolah, bahkan merupakan tumpuan utama peningkatan mutu pendidikan di sekolah. Dalam rangka menjaga mutu Sumber Daya Manusia (dalam hal ini adalah guru), maka dalam kegiatan manajamen Sumber Daya Manusia dapat menerapkan beberapa cara, antara lain melalui penerapan fungsi manajerial dan fungsi operasional dalam manajemen Sumber Daya Manusia (MSDM). Fungsi manajemen meliputi perencanaan, pengorganisasian, pelaksanaan dan pengawasan, sedangkan fungsi operasional meliputi fungsi pengadaan, fungsi pengembangan, fungsi kompensasi, fungsi intergrasi dan fungsi pemeliharaan (Wukir, 2013: 52).

Fungsi-fungsi tersebut diterapkan harus melihat kondisi yang ada di sekolah, karena bagi sekolah negeri masalah pengadaan bukan menjadi wilayah kerja sekolah. Hal ini disebabkan sistem sekolah negeri pengadaan pegawai merupakan kewenangan pemerintah, dan pihak sekolah perlu memperhatikan fungsi yang lain terutama fungsi pengembangan, fungsi kompensasi, fungsi intergrasi dan fungsi pemeliharaan. Fungsi - fungsi tersebut lebih fokus penekanan pada peningkatan Sumber Daya Manusia (guru) karena guru adalah agent of change di sekolah. Pekerjaan sebagai guru adalah pekerjaan keprofesian, karena untuk menjadi guru yang profesional seseorang harus menempuh pendidikan profesi. Seperti yang tercantum pada UU No.1 4 Tahun 2005 tentang guru dan dosen pasal 1 butir 1 disebutkan bahwa Guru adalah pendidik profesional dengan tugas utama mendidik, mengajar, membimbing, mengarahkan, melatih, menilai, dan mengevaluasi peserta didik pada pendidikan anak usia dini jalur pendidikan formal, pendidikan dasar, dan pendidikan menengah

Guru yang profesional memiliki empat kompetensi, yaitu meliputi kompetensi pedagogik, kompetensi kepribadian, kompetensi sosial, dan kompetensi profesional yang diperoleh melalui pendidikan profesi (UU RI No. 14 Tahun 2005 pasal 10 butir 1).

Seorang guru yang profesional merupakan sumber daya manusia yang unggul, karena guru yang profesional memiliki ciri-ciri, antara lain : (1) memiliki keahlian mendidik dalam bidangnya, (2) memiliki rasa tanggung jawab yang berkomitmen dan peduli terhadap 
tugasnya, dan (3) memiliki rasa kesejawatan, menghayati tugasnya sebagai guru serta mampu menjaga kode etik profesinya (Sahartien,2010:2).

Dalam rangka mewujudkan guru yang profesional perlu adanya kegiatan peningkatan mutu guru. Adapun cara meningkatkan mutu guru dapat melalui beberapa cara seperti menerapkan fungsi pengembangan, pembinaan, kompensasi dan fungsi pengawasan (supervisi). Supervisi menurut Suhardan (2010) adalah pengawasan terhadap kegiatan akademik yang berupa proses belajar mengajar, pengawasan terhadap guru dalam mengajar, pengawasan terhadap murid yang belajar dan pengawasan terhadap situasi yang menyebabkannya. Pengawasan dalam pendidikan merupakan pelayanan terhadap kebutuhan pokok guru agar mampu meningkatkan potensinya sehingga benar-benar menjadi sumber daya manusia di sekolah yang profesional secara berkesinambungan. Adapun pelaksanaan kegiatan supervisi di sekolah, sepenuhnya menjadi tanggung jawab kepala sekolah, karena salah satu tugas pokok kepala sekolah adalah sebagai supervisor. Fenomena yang terjadi di SD Negeri 001 Gunung Kijang yang berkaitan dengan aktivitas guru dan kepala sekolah dalam melaksanakan tugasnya adalah sebagai berikut: (1) Sebagian besar guru masih menerapkan pembelajaran yang konvesional dengan metode ceramah, tanya jawab, pemberian tugas; (2)

Minat dan motivasi guru dalam inovasi yang masih rendah, hal ini ditunjukkan dengan adanya sikap guru yang cenderung apatis dengan adanya berbagai pembaharuan, dan merasa nyaman dengan kondisi rutinitas; (3)

Dalam melaksanakan pembelajaran guru jarang menggunakan media, sehingga pembelajaran cenderung membawa siswa hanya untuk membayangkan apa yang dipelajari (pembelajaran kurang nyata/riil); (4) Guru sering tidak mengerjakan administrasi akademik (RPP dibuat dengan mengcopy milik orang lain, adminisrasi penilaian dan jurnal pembelajaran belum 3 dolomen, terdokumentasi dengan baik ; (5) Guru sering meninggalkan kelas saat jam mengajar dan hadir tidak tepat waktu pada jam mengajar; (6) Supervisi dilaksanakan satu kali dalam satu semester dengan tujuan hanya untuk kepentingan administrasi PKG, tanpa disertai tindak lanjut. Berdasar informasi sementara dari kepala sekolah, guru dan siswa, permasalahan tersebut disebabkan adanya beberapa hal yang menghambat, antara lain : 1) kepengawasan (supervisi) terhadap kinerja guru dari atasan yang masih kurang karena masih terbatas pada kepentingan PKG; 2) masih banyak guru yang kurang mendukung terhadap guru guru yang mau dan mampu berinovasi; 3) fasilitas multi media yang belum tersedia secara merata di semua kelas.

Hambatan - hambatan tersebut perlu untuk segera diatasi, karena jika tidak segara diatasi akan berpengaruh pada kinerja guru dan dampak selajutnya dapat berpengaruh pada mutu lulusan/siswa sebagai muara dari kegiatan pendidikan. Berdasarkan hal tersebut dapat dikategorikan kinerja guru sebagai sumber daya manusia utama dalam pendidikan di SD Negeri 001 Gunung Kijang masih rendah, sementara tuntutan yang ada guru adalah agent of change, dan menjadi seorang yang benar-benar profesional dalam bidangnya demi terwujudnya pendidikan yang bermutu.

Sebagai upaya untuk memperbaiki kondisi tersebut, kepala sekolah selaku manajer melakukan kegiatan supervisi akademik yang ingin mewujudkan tercapainya peningkatan kinerja guru yang bermutu melalui kegiatan supervisi. Dengan melihat kondisi sekolah yang demikian, maka kepala sekolah melakukan penelitian. Mengingat jumlah guru di SD Negeri 001 Gunung Kijang tidak sedikit, maka untuk langkah awal kepala sekolah melakukan penelitian terhadap guru - guru di kelas tinggi sehingga judul penelitian yang diambil adalah : "Upaya Meningkatkan Kinerja Guru Melalui Supervisi Akademik di SD Negeri 001 Gunung Kijang"

Sumber daya manusia adalah orangorang yang bekerja di lingkungan organisasi yang memiliki beragam kemampuan, bakat, pengaruh, produktivitas, kualitas dan kemampuan lainnya (Wukir, 2013: 49).

Dalam suatu organisasi sekolah yang menjadi sumber daya manusia utama (kunci) adalah guru dan kepala (tenaga pendidika) yang kemudian dibantu oleh tenaga administrasi (TU/tenaga kependidikan). Sumber daya manusia di sekolah ini berperan menentukan keseluruhan strategi dan tujuan organisasi, medesain sistem kerja, memproduksi barang/jasa (mutu sekolah dan siswa), mengalokasikan sumber-sumber finansial dan memasarkan jasa (mutu sekolah), dan mereka bekerja sesuai dengan peranan masing-masing dalam organisasi sekolah tersebut.Pengembangan sumber daya manusia dalam organisasi suatu sekolah merupakan usaha untuk 
memperbaiki kapasitas kemampuan guru/tenaga pendidik dan tenaga kependidikan/TU supaya lebih produktif. Pengelolaan sumber daya manusia merupakan hal yang penting dalam organisasi sekolah karena sekolah yang bermutu tergantung dengan sumber daya manusia sebagai agent of change di sekolah.

Berkaitan dengan startegi pengelolaan sumber daya manusia Wukir (2012: 49) menyebutnya sebagai manajemen sumber daya manusia dimana pengeleloannya juga meliputi kebijakan dan kegiatan-kegiatan yang harus dilaksanakan oleh manajer. Jika diterapkan di sekolah hal ini merupakan tugas pokok kepala sekolah, karena salah satu fungsi kepala sekolah adalah juga sebagai manajer.

Adapun tujuan pengelolaan tenaga pendidik dan tenaga kependidikan (guru dan TU) menurut Aas Syaefudin (2005: 103) dalam Herawan \& Hartini (2012: 232) adalah supaya mereka mempunyai kemampuan, motivasi dan kratifitas untuk: 1) mewujudkan sistem sekolah yang mampu mengatasi kelemahannya sendiri; 2) secara berkesinambungan menyesuaikan program pendidikan sekolah terhadap tututan dan kebutuhan peserta didik dalam menghadapi persaingan secara sehat dan dinamis; 3) menyediakan kader pemimpin pendidikan yang handal dan dapat menjadi teladan. Dalam usaha mencipatakan guru sebagai sumber daya manusia di sekolah, dalam UU No. 14 Tahun 2005 pasal 20, guru harus melaksanakan tugas, yaitu: (1) merencanakan pembelajaran, melaksanakan proses pembelajaran yang bermutu, serta menilai dan mengevaluasi hasil pembelajaran; (2) meningkatkan dan mengembangkan kualifikasi akademik dan kompetensi secara berkelanjutan sejalan dengan perkembangan ilmu pengetahuan, teknologi, dan seni; bertindak objektif dan tidak diskriminatif atas dasar pertimbangan jenis kelamin, agama, suku, ras, dan kondisi fisik tertentu, atau latar belakang keluarga, dan status sosial ekonomi peserta didik dalam pembelajaran; (4) menjunjung tinggi peraturan perundangundangan, hukum, dan kode etik guru, serta nilainilai agama dan etika; dan ) memelihara dan memupuk persatuan dan kesatuan bangsa.'Dalam menghadapi tantangan abad 21 menurut Surya, M.H. (2004: 38-41) guru sebagai Sumber Daya Manusia di sekolah hendaknya memiliki tiga profil, yaitu : (1) Memiliki semangat juang yang tinggi; (2) Mampu mengikuti perkembangan jaman dan iptek; (3) Mampu belajar dan bekerja sama dengan profesi lain.

Dari ketiga pendapat tersebut, dapat disimpulkan bahwa supervisi akademik adalah kegiatan pengawasan terhadap kegiatan pembelajaran yang dilaksanakan guru dalam rangka meningkatkan mutu pembelajaran, sehingga proses belajar mengajar akan mampu menghasilkan mutu lulusan yang baik.

Dalam Sagala (2010) tujuan supervisi adalah membantu guru untuk mengembangkan bagaimana meningkatkan kemampuan dan kapasitasnya, supaya siswa dapat mewujudkan tujuan belajarnya. Dalam hal ini supervisi dilaksanakan dalam rangka memberikan bantuan pada guru berkaitan dengan pelaksanaan PBM, seperti yang dijelaskan oleh Sahertian (2010: 19) bahwa tujuan supervisi akademik memberikan layanan dan bantuan untuk mengembangkan situasi belajar mengajar yang dilakukan guru di kelas. Berdasar dua pendapat tersebut maka dapat dikatakan bahwa supervisi akademik memberikan layanan dan bantuan pada guru sebagai sumber daya manusia untuk meningkatkan kualitas mengajarnya dalam rangka mencapai kualitas lulusan yang bermutu pula.

Prinsip-prinsip supervisi akademik yang ditulis oleh Sahertian (2010: 20) adalah: (1) Prinsip ilmiah (scientefic), yaitu kegiatan supervisi dilaksanakan berdasar data obyektif yang diperoleh pada pelaksanaan proses belajar mengajar melalui wawancara (alat perekam), angket, observasi dan pelaksanaanya secara sistematis, berencana serta kontinu; (2) Prinsip demokratis, yaitu menjujung tinggi harga diri dan martabat guru, bukan berdasarkan hubungan atasan bawahan, tapi berdasarkan rasa kesejawatan; (3) Prinsip kerjasama, yaitu mengembangkan usaha bersama atau menurut istilah "supervisi sharing of idea, sharing of experience" memberi support, dorongan, menstimulus guru, sehingga mereka merasa tumbuh bersama; dan (4) Prinsip konstruktif dan kreatif, yaitu supervisi yang mampu mencipatakan suasana kerja yang menyenangkan sehingga guru-gulru termotivasi untuk mengembangkan potensi kreatifitasnya.

Menurut Swearingen (1961) dengan bukunya yang berjudul Supervision of Instrumen Foundation and Dimension dalam Sahaertian (2010 21) terdapat delapan fungsi supervisi yaitu: (1) mengkoordinasi semua usaha sekolah; (2) memperlengkapi pememimpinan sekolah; (3) memperluas pengalaman guru-guru; 
(4) menstimulasi usaha-usaha yang kreatif; (5) memberi fasilitas dan penilaian yang terus-menerus; (6) menganalisis situasi belajar mengajar; (7) memberikan pengetahuan dan ketrampilan pekada setiap anggota staf; dan (8) memberi wawasan yang lebih luas dan terintegrasi dalam merumuskan.

Seperti yang telah dijelaskan sebelumnya bahwa obyek supervisi adalah obyek pengkajian pada perbaikan proses belajar mengajar dalam arti yang luas, tetapi Olivia (1976) dalam bukunya Supervision for Today's School menggunakan istilah domain, dengan memberikan tiga sasaran supervisi pendidikan yang meliputi tiga domain, yaitu perbaikan pengajaran, pegembangan kurikulum dan pengembangan staf (Sahertian sendiri, 2010: 27). Sedangkan Sahertian sendiri menuliskan bahwa pada masa mendatang supervisi memliki empat obyek yaitu: (1) Pembinaan Kurikulum; (2) Perbaikan proses pembelajaran; (3) Pengembangan staf dan (4) Pemeliharaan dan perawatan moral serta semangat kerja guru.

Teknik supervisi ada dua jenis, yaitu teknik supervisi individual dan teknik supervisi kelompok (Sahertian, 2010: 34). Tekik supervisi individual dilakukan dengan beberapa cara, yaitu: (1) kunjungan Kelas, (2) observasi kelas, (3) percakapan piribadi, (4) inter-visitasi, (5) menyeleksi berbagai sumber bahan mengajar, dan (6) menilai diri sendiri. Tekni supervisi kelompok ada beberapa cara, yaitu: (1) pertemuan orientasi bagi guru baru, (2) panitia penyelenggara, (3) rapat guru, (4) studi kelompok antar guru, (5) diskusi sebagai proses kelompok, 6) tukar-menukar pengalaman, 7) lokakarya/workshop, 8) diskusi panel, 9) seminar, 10) simposium, 11) demosntarsi mengajar, 12) perpustakaan jabatan, 13) buletin supervisi, 14) membaca langsung, 15) mengikuti kursus, 16) organisasi jabatan, 17) laboratorium kurikulum, dan 18) perjalanan sekolah untuk anggota staf.

Prosedur supervisi akademik adalah rangkaian program kegiatan supervisi, menurut Kemendikbud (2015: 17-18) prosedur supervisi akademik terdiri atas : (1) Tahap persiapan, meliputi menyiapkan instrumen dan menyiapkan jadwal bersama; (2) Tahap pelaksanaan, yaitu pelaksanaan observasi supervisi baik secara langsung maupun tidak langsung; (3)Tahap pelaporan, meliputi mengidentifikasi hasil pengamatan pada saat observasi, menganalisa hasil supervisi, mengevaluasi bersama, kemudian membaut catatan hasil supervisi sebagai dokumen untuk pelaporan; Tahap tindak lanjut, meliputi: berdiskusi dan membuat solusi bersama, menyampaikan hasil pelaksanaan supervisi akademik dan mengkomunikasikan hasil supervisi akademik kepada kepala sekolah dan guru; (4) Tahap tindak lanjut, meliputi: berdiskusi dan membuat solusi bersama, menyampaikan hasil pelaksanaan supervisi akademik dan mengkomunikasikan hasil supervisi akademik kepada guru.

Kinerja atau prestasi kerja (performance) diartikan sebagai ungkapan kemampuan yang didasari oleh pengetahuan, sikap, keterampilan dan motivasi untuk menghasilkan sesuatu. Kinerja guru pada dasarnya merupakan kinerja atau unjuk kerja yang dilakukan oleh guru dalam melaksanakan tugasnya sebagai pndidik, dan kualitas guru akan sangat menentukan kualitas hasil pendidikan, karena guru merupakan pihak yang paling banyak bersentuhan langsung dengan siswa dalam proses pembelajaran di lembaga pendidikan sekolah, dah hal ini tidak hanya ditentukan dari salah satu faktor saja, namun banyak hal yang ikut berpengaruh dalam menentukan peningkatan kinerja guru tersebut.

Pengertian Kinerja Guru Menurut Rivai (2005:14) kinerja merupakan terjemahan dari kata performance yang didefinisikan sebagai hasil atau tingkat keberhasilan seseorang secara keseluruhan selama periode tertentu untuk melaksanakan tugas dibandingkan dengan berbagai kemungkinan, seperti standar hasil kerja, target atau sasaran atau kriteria yang telah ditentukan terlebih dahulu dan telah disepakati bersama.

Pendapat tentang kinerja guru tersebut di atas senada dengan Mangkunegara, Anwar A (2006:67) yang menyatakan bahwa Kinerja (prestasi kerja) adalah hasil kerja secara kualitas dan kuantitas yang dicapai oleh seorang pegawai dalam melaksanakan tugasnya sesuai dengan tanggug jawabyang diberikan kepadanya. Sejalan dengan hal tersebut di atas, menurut pendapat Sedarmayanti (1995:53) dalam Suharsaputra (2010:146), bahwa pengertian kinerja menunjuk pada ciri-ciri atau indikator sebagai berikut: "Kinerja dalam suatu organisasi dapat dikatakan meningkat jika memenuhi indikator-indikator antara lain: kualitas hasil kerja, ketepatan waktu, inisiatif, kecakapan, dan komunikasi yang baik".

Berdasarkan beberapa definisi yang dikemukakan di atas, dapat dinyatakan bahwa kinerja guru merupakan prestasi yang dicapai oleh seseorang guru dalam melaksanakan tugasnya atau pekerjaannya selama periode tertentu sesuai 
standar kompetensi dan kriteria yang telah ditetapkan untuk pekerjaan tersebut. Kinerja seorang guru tidak dapat terlepas dari kompetensi yang melekat dan harus dikuasai. Kompetensi guru merupakan bagian penting yang dapat menentukan tingkat kemampuan guru dalam melaksanakan tugasnya sebagai seorang pengajar yang merupakan hasil kerja dan dapat diperlihatkan melalui suatu kualitas hasil kerja, ketepatan waktu, inisiatif, kecepatan dan komunikasi yang baik.

\section{METODE PENELITIAN}

Penelitian ini berlokasi di SD Negeri 001 Gunung Kijang, yang mana penelitian ini dilakukan pada waktu guru melakukan proses belajar mengajar, dan waktu-waktu luang seperti istirahat. Penelitian ini dilaksanakan pada semester I dan memakan waktu kurang lebih 3 (tiga) bulan dimulai pada bulan Agustus sampai bulan Oktober Tahun Pelajaran 2019/2020.

Pada Penelitian ini yang menjadi subjek penelitian ini adalah seluruh guru pada SD Negeri 001 Gunung Kijang dengan jumlah guru sebagai subjek sebanyak 15 orang, terdiri dari 11 guru berstatus PNS dan 4 guru honor .

Sumber data dalam penelitian ini adalah sebagai berikut: (1) Pengamatan terhadap kinerja guru dalam menguasai pembelajaran pada kurikulum sekolah; (2) Pengamatan terhadap kemampuan guru dalam menyusun Rencana Pelaksanaan Pembelajaran (RPP); (3) Pengamatan terhadap kemampuan guru dalam menguasai kelas dalam Proses Belajar Mengajar (PBM); (3) Pengamatan terhadap kemampuan guru dalam penggunaan media sumber belajar, dapat mengendalikan, memiliki dan menggunakan, serta membuat alat-alat sederhana. dalam Proses Belajar Mengajar (PBM); (4) Pengamatan terhadap kelengkapan administrasi guru.

Tehnik pengumpulan data pada penelitian ini adalah terdiri atas dua kegiatan pokok yaitu pengumpulan data awal diambil dari kunjungan langsung ke kelas, Data awal kerja guru dan efektifitas pembelajaran dilihat dari hasil supervisi kunjungan kelas masing-masing guru yang dilaksanakan tanpa pemberitahuan atau pemberitahuan terlebih dahulu.

Data hasil analisis setiap siklus serta tanggapan lain dari guru terhadap pelaksanan program pemantauan atau pengamatan, dilaksanakan seiring dengan peneltian berlangsung. Dengan kata lain bahwa pemantauan terhadap pelaksanaan program dilaksanakan untuk melihat kinerja guru dalam mengefektifkan pembelajaran yang telah diberikan.

Indikator pencapaian yang peneliti harapkan paling rendah adalah $75 \%$ tingkat kinerja guru dalam mengajar di kelas. Adapun indikator kinerjanya adalah sebagai berikut: (1) Apabila rata-rata kinerja guru terhadap efektifitas pemebelajaran mencapai lebih dari 75 , maka dapat dikatakan adanya peningkatan; (2) Apabila rata-rata kinerja guru terhadap efektifitas pemebelajaran kurang dari 75 , dianggap belum berhasil sehingga perlu dilakukan pembinaan.

Penelitian ini mengacu kepada model siklus Kemmis S. and Mc. Taggart yang melalui beberapa langkah yaitu perencanaan, pelaksanaan, pengamatan, dan refleksi. Siklus tahap-tahap penelitian dapat dilihat pada gambar berikut :

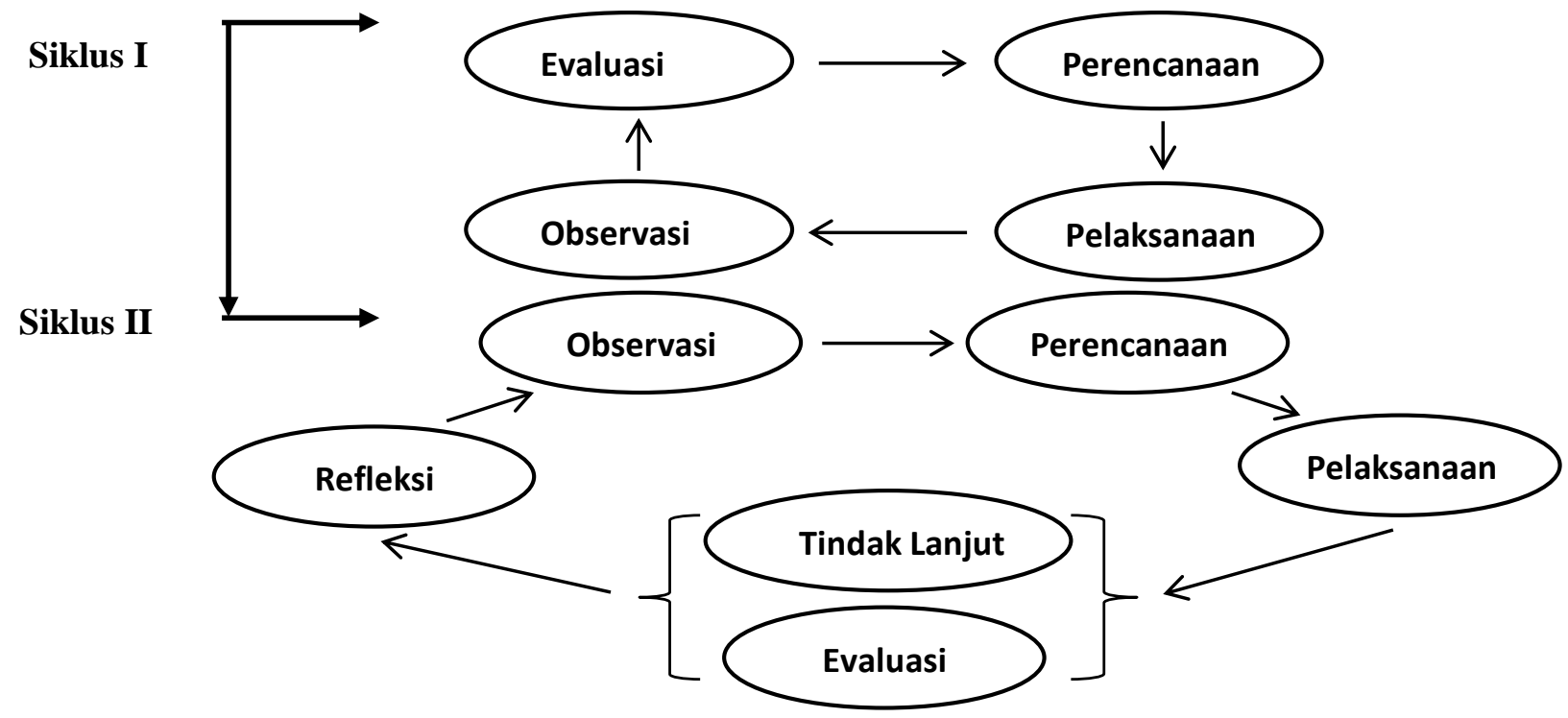

Gambar 1. Alur Penelitian 


\section{Siklus I}

Perencanaan. (1) Melakukan diskusi dengan pengamat tentang persiapan pelaksanaan supervise; (2) Menyusun jadwal supervisi klinis; (3) Menyiapkan lembar observasi/pengamatan supervisi.

Pelaksanaan.

(1) Mensosialisasikan pelaksanaan supervisi akademik melalui rapat dewan guru yang dipimpin penulis selaku kepala sekolah; (2) Melakukan supervisi terhadap kinerja guru dalam menjalankan tugas mengajar di kelas; (3) Melakukan wawancara terhadap guru yang disupervisi; (4) Memberikan bimbingan dan arahan terhadap guru sebagai upaya perbaikan terhadap kinerja guru. Observasi/pengamatan dilaksanakan selama penelitian berlangsung, dengan sasaran utama untuk melihat peningkatan kinerja guru dalam melaksanakan tugas mengajar. Instrument yang disusun untuk keperluan-keperluan pengamatan indikatornya berupa prilaku guru dalam menjalankan tugas mengajar sehari-hari. Peneliti mengkaji, melihat, dan mempertimbangkan hasil atau dampak dari tindakan yang telah dilakukan. Berdasarkan hasil dari refleksi ini, peneliti melaksanakan revisi atau perbaikan terhadap rencana yang telah disusun agar sesuai dengan yang peneliti inginkan pada tindakan siklus berikutnya.

\section{Siklus II}

Perencanaan. (1) Mendiskusikan

kelemahan yang terdapat pada siklus sebelumnya dengan pengamat kepala sekolah; (2) Merumuskan strategi perbaikan; (3) Menyiapkan lembar observasi/pengamatan supervisi.

Pelaksanaan. Peneliti memeriksa kesiapan guru sebelum mengajar di kelas., kemudian bersama observer melakukan supervisi terhadap guru yang mengajar dikelas masingmasing mulai dari kelas VII s/d kelas IX. Apa yang dilakukan oleh peneliti sebagai upaya meningkatkan kinerja guru terhadap efektifitas pembelajaran melalui supervisi akademik.

Observasi.Observasi/pengamatan

dilaksanakan selama penelitian berlangsung, dengan sasaran utama untuk melihat peningkatan kinerja guru dalam melaksanakan tugas mengajar. Instrument yang disusun untuk keperluan-keperluan pengamatan indikatornya berupa prilaku guru dalam menjalankan tugas mengajar sehari-hari.

Refleksi. Peneliti mengkaji, melihat, dan mempertimbangkan hasil atau dampak dari tindakan yang telah dilakukan. Berdasarkan hasil dari refleksi ini, peneliti menetapkan apakah penelitian dilanjutkan pada siklus berikutnya atau dihentikan pada siklus II apa bila pada siklu II penelitian dinyatakan berhasil.

\section{HASIL PENELITIAN DAN PEMBAHASAN}

Sebelum dilaksanakan penelitian yaitu pada kondisi awal (pra siklus) kinerja guru sangat rendah. Hal ini tentu saja sangat berpengaruh pada efektifitas proses pembelajaran dan dapat menyebabkan mutu pendidikan menjadi rendah. Untuk itulah peneliti berpikir keras mencari solusi bagaimana mengatasi permasalahan tersebut.

Setelah melakukan pengamatan pada kondisi awal, berdasarkan hasil pengamatan tersebut peneliti bersama observer mendiskusikan dan merumuskan usaha untuk melakukan perbaikan melalui penelitian tindakan sekolah dengan tujuan meningkatkan kinerja guru terhadap efektifitas pembelajaran.

Pada pelaksanaan tindakan siklus I menunjukkan adanya sedikit peningkatan kinerja guru terhadap efektifitas pembelajaran. Adapun hasil obeservasi tindakan pada siklus I adalah sebagai berikut. (1) Kemampuan guru menguasai materi pembelajaran yang mendapat kriteria B (baik) sebanyak 4 orang (27\%), kriteria C (cukup) 9 orang $(60 \%)$, dan kriteria D (kurang) 2 orang (13\%). Sedangkan yang mendapat kriteria A (amat baik) belum ada; (2) Kemampuan guru dalam menyususn RPP yang mendapat kriteri B (baik) ada 2 Orang (13\%), kriteria C (cukup) ada 9 orang $(60 \%)$ dan kriteria D (kurang) sebanyak 4 orang $(27 \%)$. Sedangkan kriteria A (amat baik) belum ada; (3) Kemampuan guru dalam penguasaan kelas yang mendapat kriteria A (amat baik) sebanyak 1 orang (7\%), kriteria B (baik) ada 2 orang (13\%), kriteria $C$ (cukup) ada 9 orang (60\%), dan yang mendapat kriteria D (kurang ) ada 3 orang (20\%); (4) Kemampuan Kema puan Guru dalam Melengkapi Administrasi Kelas yang mendapat kriteria A (amat baik) ada 1 orang (7\%), kriteria B (baik) ada 3 orang (20\%), kriteria C (cukup) ada 9 orang (60\%) dan kriteria D (kurang) ada 2 orang (13\%). (5) Kemampuan Guru dalam penggunaan media dan sumber belajar, mengendalikan, serta membuat alat peraga sederhana kriteria A (amat baik) belum ada, kriteria B (baik) ada 3 orang (20\%), kriteria C (cukup) ada 9 orang (60\%), dan kriteria D (kurang) ada 3 orang (20\%); (6)Berdasrkan hasil yang dicapai pada pelaksanaan tindakan siklus I tersebut, peneliti merasa belum puas atas pencapaian tersebut. Oleh karena itu peneliti melanjutkan pada siklus II dengan terlebih dahulu 
melakukan perbaikan atas kelemahan yang terjadi pada siklus sebelumnya.

Pada pelaksanaan tindakan siklus II terjadi peningkatan yang cukup signifikan. Hal ini disebakan peneliti secara terus menerus melakukan bimbingan dan arahan kepada guru agar memiliki kesadaran diri dan tanggung jawab sebagai pendidik untuk meningkatkan kinerja sehingga proses pembelajaran menjadi lebih efektif yang pada akhirnya akan meningkatkan mutu pendidikan. Adapun hasil tindakan pada siklus II adalah sebagai berikut: (1)Kemampuan guru menguasai materi pembelajaran yang mendapat kriteria A (amat baik) ada 8 orang ( $53 \%$ ) kriteria B (baik) sebanyak 6 orang (40\%), kriteria C (cukup) 1 orang (7\%), Sedangkan yang mendapat kriteria D (kurang) sudah tidak ada lagi; (2) Kemampuan guru dalam menyususn RPP yang mendapat kriteri A (amat baik) ada 6 orang ( $40 \%$ ), kriteria B (baik) ada 7 orang (47\%), kriteria C (cukup) ada 2 orang (13\%) Sedangkan kriteria D (kurang) sudah tidak ada lagi; (3)Kemampuan guru dalam penguasaan kelas yang mendapat kriteria A (amat baik) sebanyak 8 orang (53\%), kriteria B (baik) ada 6 orang $(40 \%)$, kriteria $\mathrm{C}$ (cukup) ada 1 orang (7\%), dan yang mendapat kriteria D (kurang ) tidak ada; (4) Kemampuan Guru dalam Melengkapi Administrasi Kelas yang mendapat kriteria A (amat baik) ada 7 orang (47\%), kriteria B (baik) ada 6 orang $(40 \%)$, kriteria $C$ (cukup) ada 2 orang (13\%) dan kriteria D (kurang) tidak ada; (5) Kemampuan Guru dalam penggunaan media dan sumber belajar, mengendalikan, serta membuat alat peraga sederhana ada 8 orang $(53 \%)$ yang mempunyai nilai amat baik, 6 orang $(40 \%)$ yang mempunyai nilai baik, 1 orang $(7 \%)$ yang nilainya masih cukup dan kriteria D (kurang) tidak ada lagi.

Berdasrkan hasil yang dicapai pada pelaksanaan tindakan siklus II tersebut, peneliti merasa puas atas keberhasilan tersebut. Oleh karena itu peneliti menghentikannya pada siklus II karena sudah dianggap berhasil.

\section{SIMPULAN DAN SARAN Simpulan}

Berdasarkan kegiatan supervisi akademik yang telah dilaksanakan oleh peneliti, maka dapat disimpulkan bahwa kegiatan supervisi akademik mampu meningkatkan keseluruhan aspek yang menjadi titik kelemahan guru yang menjadi permasalah di SD Negeri 001 Gunung Kijang Kabupaten Bintan. Aspek - aspek kelemahan guru telah mengalami penurunan dan menunjukkan hasil ke arah yang positif atau sudah dapat teratasi, mulai dari kedisiplinan masuk jam mengajar, ketertiban dokumen akademik, kesadaran terhadap inovasi pendidikan, penerapan CTL, pemanfaatan media dan internet dalam pembelajaran, serta penggunaan IT dalam aktifitas akademik sudah mengalami perubahan ke arah postif (meningkat), meskipun belum mencapai kesempurnaan.

\section{Saran}

Peningkatan kinerja guru dapat dilaksanakan dengan berbagai cara dengan memperhatikan kondisi nyata yang ada dan permasalahan yang dihadapi pihak sekolah sehingga dalam penyelesaian, harus dipilih metode yang tepat untuk mendapatkan hasil yang maksimal.

\section{DAFTAR PUSTAKA}

Alfabeta.Suhardan, Dadang, 2010. Supervisi Profesional. Bandung:

Alfabeta.Kemendikbud. 2005. Undang-Undang Guru dan Dosen No. 14 Tahun 2005. Jakarta:

Alfabeta.Masaong, H.A. Kadim, 2012. Supervisi Pembelajaran dan

Pengembangan Kapasitas Guru (Memberdayakan Pengawas Sebagai Gurunya Guru). Bandung:

Alfabeta.Sahertian, Piet. A. 2010. Konsep Dasar dan Teknik Supervisi Pendidikan dalam Rangka Pengembangan Sumber Daya Manusia, Jakarta:

Herawan \& Hartini. 2012. Manajemen Tenaga Pendidik dan Kependidikan dalam Manajemen Pendidikan Dosen Administrasi Pendidikan UPI. Bandung:

Kemendikbud.Pemendikbud, 2015. Supervisi manajerial dan Supervisi Akademik, Jakarta:

Menteri Negara PAN \& Reformasi Birokrasi RI.Sagala, Syaiful. 2010. Supervisi Pembelajaran dalam Profesi Pendidikan. Bandung:

PPTK-BPSDMP\&PMP Kemendikbud.Permenpan \& Reformasi Birokrasi No. 16 Tahun 2009 Tentang Jabatan Fungsional Guru dan Angka Kreditnya. Jakarta:

Rineka Cipta. . 2004. Bunga Rampai Guru dan Pendidikan. Jakarta: Balai Pustaka.Wukir, 2013. Manajemen Sumber Daya Manusia dalam Organisasi Sekolah. Yogyakarta: Multi Presindo 